\title{
The Role of Glycoprotein 96 in the Persistent Inflammation of Rheumatoid Arthritis
}

\author{
Qi-Quan Huang, MD and \\ Northwestern University Feinberg School of Medicine, Department of Medicine, Division of \\ Rheumatology, 240 East Huron, McGaw M220, Chicago, IL 60611, Phone: 312/908-1965; FAX \\ 312/503-0994; qqhuang@northwestern.edu

\section{Richard M. Pope, MD} \\ Northwestern University Feinberg School of Medicine, Department of Medicine, Division of \\ Rheumatology, 240 East Huron, McGaw M300, Chicago, IL 60611, Phone: 312-503-8003; Fax: \\ 312-503-0994; rmp158@northwestern.edu
}

\begin{abstract}
The 96-kDa glycoprotein (gp96) is an endoplasmic reticulum (ER) resident molecular chaperone. Under physiologic conditions, gp96 facilitates the transport of toll-like receptors (TLRs) to cell or endosomal membranes. Under pathologic circumstances such as rheumatoid arthritis, gp96 translocates to the cell surface and extracellular space, serving as an endogenous danger signal promoting TLR signaling. Macrophages play a central role in regulating innate and adaptive immunity, and are the major source of proinflammatory cytokines and chemokines in rheumatoid arthritis (RA). Macrophage numbers in the sublining of RA synovial tissue correlate with clinical response. This review focuses on the recent findings that implicate gp96 induced macrophage activation mediated through TLR signaling in the pathogenesis of RA and provides insights concerning the targeting gp96 and the TLR signaling pathway as therapeutic approaches for patients with RA and possibly other chronic inflammatory conditions.
\end{abstract}

\section{Introduction}

The 96-kDa glycoprotein (gp96) is an endoplasmic reticulum (ER) resident protein belonging to the heat shock protein (HSP) 90 family based on its molecular mass, which is $50 \%$ homologous with other human HSP90 isoforms $[1,2]$. While gp96 shares features with HSPs, it is distinct from other cytosolic HSP90 proteins structurally and functionally. For example, gp96 functions as a molecular chaperone, is up-regulated in response to cellular stress, and shares common functional domains such as the N-terminus ATP binding activation domain, an charged middle domain and a C-terminal dimerization domain [3-7]. However, gp96 has a unique C-terminal KDEL motif which serves as a molecular anchor for its ER retention [8], and it lacks the C-terminal RMEEVD sequence shared by HSP 90 and 70 [9]. This review describes recent findings concerning the interaction between TLRs and gp96 and focuses on the potential role of gp96 in the pathogenesis of rheumatoid arthritis (RA).

\footnotetext{
(C) 2012 Elsevier Inc. All rights reserved.

Correspondence to: Richard M. Pope.

Publisher's Disclaimer: This is a PDF file of an unedited manuscript that has been accepted for publication. As a service to our customers we are providing this early version of the manuscript. The manuscript will undergo copyediting, typesetting, and review of the resulting proof before it is published in its final citable form. Please note that during the production process errors may be discovered which could affect the content, and all legal disclaimers that apply to the journal pertain.
} 


\section{HSP and TLR Mediated Immunity}

Toll-like receptors (TLRs) are a group of pattern recognition receptors, that recognize Pathogen Associated Molecular Patterns (PAMPs) expressed on microbial pathogens or Danger Associated Molecular Patterns (DAMPs). TLRs are expressed primarily on monocytes, macrophages and dendritic cells. TLR ligation initiates inflammatory and innate, and subsequently adaptive immune responses [10]. Ligation of the TLR receptors results in the induction of proinflammatory cytokines or type I interferon $\alpha$ and $\beta$, mediated through MyD88 (all TLRs except TLR3) or the TRIF pathway (TLR3 and TLR4) [10-13].

HSPs, including gp96, have been implicated in immunity for about 2 decades. Immunization with gp96 isolated from tumors is capable of inducing a tumor-specific immune response mediated by CD8+ T cells $[14,15]$. The mechanism for HSP induced immunity was identified as a receptor-mediated event, following uptake of gp96 bound to tumor derived peptides by antigen-presenting cells or natural killer (NK) cells. Many specific receptors have been identified in mediating HSP-induced immunity, including CD91, CD94, Scavenger-A (SR-A) and TLRs [14-17]. Additionally, many HSP proteins have been identified as potential ligands for TLR2 or TLR4, including HSP22, HSP 60, HSP70, HSP90 and gp96 [18-22]. However, more recent evidence suggests that some reported activities are from the contaminating endotoxin, a TLR4 ligand, acquired during recombinant protein preparation [23]. Specifically, initial publications demonstrating the ability of HSP60 and HSP70 to act as TLR4 ligands, could not be confirmed, with preparations that were highly purified to remove endotoxin [24, 25]. Employing very low endotoxin recombinant HSP22, we were not able to confirm its ability to activate through TLR4 (data not shown). Therefore, careful analysis is required to exclude microbial contamination when identifying and potential endogenous TLR ligand.

\section{Gp96 and TLR}

\section{Gp96 as a TLR Chaperone}

Since the first demonstration of gp96 as a chaperone for immunoglobulin chains in 1992 [26], additional gp96 clients have been identified including many cell surface receptors or ligands engaged in innate and adaptive immunities and cell-to-cell communication, such as Toll-like receptors (TLRs), integrins and immunoglobulins [5, 7, 27-29]. Gp96 as TLR chaperone was first described by Randow and Seed a decade ago, employing the mutant murine pre-B-cell line (70Z/3), which lacks gp96 [27]. This mutant line is unresponsive to LPS, LTA and PGN ligation. Reintroduction of gp96 restores the TLR1, TLR2 and TLR4 cell surface expression, as well as responsiveness to TLR ligation, thus showing that gp96 is required for cell surface expression of TLR1, TLR2 and TLR4 [27]. Gp96 was later identified to be a master chaperone for TLRs employing macrophages from a mouse conditional gp96 knockout line [28]. Macrophages deficient in gp96 fail to express TLRs on the cell surface or in the endosomal compartment. Although expressed, in the absence of gp96, TLRs fail to translocate to the cell surface or endosome, and are largely retained in the ER and do not respond to their respective ligands [28].

\section{Gp96 as a TLR Ligand}

During pathological situations or under cellular stress, gp96 may translocate to the cell surface or gain extracellular access [21, 30-36]. Extracellular gp96 may act as an autoantigen to induce auto-antibodies [37, 38], modulate antigen presentation, and function as an endogenous adjuvant, enhancing immune responses [4, 39, 40]. Gp96 has also been identified as TLR ligand promoting pro-inflammatory cytokine/chemokines activating innate immune responses [21, 22]. Thus, gp96 may provide a "danger signal" contributing to the induction of autoimmune and inflammatory disorders. 
Gp96 is capable of activating the TLR signaling pathways determined by the ability to induce proinflammatory cytokines and chemokines. Highly purified N-terminal domain of gp96 with very low endotoxin was employed to activate bone marrow-derived dendritic cells, resulting in the induction of IL-6, IL-12 p40, and keratinocyte derived-chemokine, in a dosage dependent manner. The activation was enhanced by LPS and Pam3, but not the TLR3 ligand poly-I:C, or the TLR9 ligand CpG [22]. Using the same preparation of gp96, we demonstrated that gp96 activates primary human macrophages to produce IL-6 and TNF $a$ [21]. Activation is abrogated by heat denaturation and proteinase $\mathrm{K}$ digestion, but not to endotoxin inhibitor Polymyxin-B, suggesting that endotoxin contamination did not contribute to the results. In addition, macrophage activation was inhibited by neutralizing antibodies to gp96 or TLR2, but not neutralizing antibodies to TLR4. Further, the TLR2 expressing cell line (HEK-TLR2) is strongly activated by the very low endotoxin gp96, while the activation of HEK-TLR4 cells is minimal. We also demonstrated that recombinant gp96 induces the expression of TLR2, but not TLR4. These observations document that although gp96 binds both TLR2 and TLR4, it activates macrophages primarily via the TLR2 signaling pathway [21]. The molecular mechanism for this selectivity for TLR2 activation remains to be determined.

\section{Gp96 and TLR Binding}

The direct protein-protein interaction of gp96 with receptors on antigen presenting cells is required for its ability to promote cellular responses, such as TLR2-mediated inflammatory, or CD91 or SR-A-mediated tumor-specific immune responses [27, 41]. Interestingly, $N$ linked glycans in gp96 increased gp96's binding to RAW264.7 cell surface receptors, but decreased the ability of the gp96 to induce pro-inflammatory cytokines [41]. We demonstrated that macrophage-expressed gp96 binds the extracellular domain of TLR2 and TLR4, employing recombinant TLR-Fc fusion proteins [21]. Further, recombinant Nterminal domain of gp96 also binds with TLR2 and TLR4 [21]. These observations directly demonstrate that gp96, or its Nterminal fragment, is capable of binding to TLR2 and TLR4. There is no information documenting the binding of the C- terminus of gp96 with TLR2 and TLR4. However, gp96 remains associated with TLR9 during intracellular trafficking [42], and a recent study reported that gp96 with a deleted C-terminus fails to bind with TLR9, suggesting the role of the C-terminal domain in binding to TLR9 [43].

\section{TLRS in Rheumatoid Arthritis}

\section{Rheumatoid Arthritis}

RA is a multifactorial autoimmune disease characterized by chronic and progressive joint inflammation that affects $1 \%$ of population. It primarily affects synovial tissue resulting in hyperplasia of the synovial lining composed of macrophages and fibroblasts, with infiltration of the sublining region with a variety of cells including macrophages, fibroblasts, $\mathrm{T}$ and $\mathrm{B}$ lymphocytes, and dendritic cells. Each of these cell types has been implicated in disease pathogenesis. If not successfully treated, the disease leads to progressive cartilage and bone destruction and ultimately to significant disability and reduced quality of life [4446]. About $60-70 \%$ of patients with RA share a common sequence in HLA-DR $\beta 1$ locus called the shared epitope, which contributes to the generation of autoantibodies to citrullinated proteins and formation of pathogenic immune complexes. These immune complexes are capable of activating macrophages, resulting in the expression of proinflammatory cytokines and chemokines. There is a growing body of data supporting the role of endogenous TLR ligands as contributors to the persistence of joint inflammation and the progression of joint destruction that is observed in RA. Macrophages play central roles in TLR mediated responses and are the major source of proinflammatory cytokines in RA $[45,47]$. Supporting the importance of macrophages in RA, macrophage numbers in the 
sublining of synovial tissue correlate with clinical response, identifying synovial tissue macrophages as a biomarker for the clinical course [48].

\section{Increased TLR Expression in RA}

TLR signaling pathways have been implicated as potential contributors in the pathogenesis of RA, and may represent a novel therapeutic target $[11,12]$. The persistent expression of proinflammatory cytokines and chemokines such as TNFa, IL-1 $\beta$, IL-6 and IL-8 is central to the pathogenesis of RA, supporting the potential role of TLR signaling in RA. The increased expression of TLR receptors on cells from patients from RA has been observed by many investigators [11, 49]. Increased TLR2 and TLR4 expression is observed in monocytes from peripheral blood [50-52], macrophages from synovial fluid [52] and synovial tissue of patients with RA [50,53]. TLR2 is highly expressed in the pannus, where RA synovial tissue erodes into bone and cartilage [54]. Increased TLR2 and TLR4 are also detected in RA synovial fibroblasts compared to those from patients with osteoarthritis [55]. Further, TLRs $1-6$, but not $7-10$, are expressed by isolated RA synovial fibroblasts [56] and are up-regulated upon stimulation with TNF $a$ or IL-1 $\beta$ [54]. Endosomal TLR3 and TLR7 are expressed in RA synovial tissues [50, 53, 57], and TLR3 and TLR4 are highly expressed in early as well as in longstanding RA [56].

\section{Increased Response of RA Synovial Fluid Macrophages RA to microbial TLR Ligands}

Activation of macrophages, monocytes, and fibroblasts from patients with RA with microbial TLR ligands results in the production of proinflammatory cytokines (e.g. TNF a, IL-6, IL-15), chemokines (IL-8, MMPs), and IFN $\gamma$ [13, 52, 58-61]. We have demonstrated that macrophages obtained from the synovial fluid of patients with RA respond more avidly to microbial TLR2 and TLR4 ligands compared with control or RA peripheral blood monocytes, normal in vitro differentiated macrophages, or macrophages isolated from the synovial fluids of patients with other forms of arthritis such as psoriatic arthritis [21]. This increased responsiveness may be related to decreased production of or response to IL-10 or the increased production of interferon- $\gamma$. Further, we recently demonstrated that in addition to the increased activation by stimulating with a TLR2 or TLR4 ligand, the activation with suboptimal concentrations of TLR2 and TLR4 ligands results in synergistic activation of RA synovial fluid macrophages, compared with control in vitro differentiated macrophages [62]. These observations demonstrate that macrophages obtained from the joints of patients with RA are highly responsive to TLR ligands, supporting the potential role of TLR signaling in the pathogenesis of RA.

\section{Endogenous Danger Signals in RA}

Accumulating data suggests that normal structural or intracellular molecules may become the DAMPs, which are capable of serving as endogenous TLR ligands in RA [63-65]. Although a number of potential endogenous TLR ligands have been identified in the joints of patients with RA, including HSPs 22,60 , and 70, high mobility group box 1 protein (HMGB), biglycan and fibrinogen [18-20, 66-68], as described above, concerns for the microbial TLR contamination remains and their authenticity as endogenous ligands in RA remains to be determined. We have recently identified the HSP90 family member, gp96, as a DAMP [21, 62]. Below we will provide evidence supporting the role of gp96 and other molecules as potential pathogenic endogenous TLR ligands in RA. 


\section{Gp96 as the Endogenous Candidate Promotes Persistent Inflammation of RA via TLR Signaling}

\section{Gp96 is Highly Expressed and Extracellular Exposures in RA}

Gp96 expression is increased in the RA joint. Gp96 is highly expressed in the lining and the sublining of synovial tissues from patients of RA either at the time of joint replacement surgery or when tissues are obtained by arthroscopy at the initiation or change in therapy, compared with tissues from patients with osteoarthritis or arthritis-free controls examined by immunohistochemistry [21]. The majority of cells expressing gp96 in the sublining had the morphological appearance of macrophages. Gp96 expression in the synovial lining is highly correlated to lining thickness and to the inflammatory scores in the sublining. These observations demonstrate that gp96 is highly expressed in RA and that its expression correlates with inflammation [21].

Gp96 is normally localized to the ER, but to serve as an endogenous TLR2 or 4 ligand it must become extracellular. To determine if gp96 was extracellular in RA, we examined the synovial fluid of patients with RA and controls [21]. Employing quantitative ELISA and Western blot, the concentration of full length gp96 detected in the synovial fluids is significantly greater in patients with RA compared to patients with other forms of inflammatory arthritis, such as psoriatic arthritis, and osteoarthritis. Of note, there is a positive in vivo relationship between the concentration of gp96 in synovial fluid and the intensity of TLR2 expressed on macrophages isolated from the same synovial fluid samples. In contrast, there is no correlation between gp96 level and macrophage TLR4 expression. Further, we demonstrated the increased expression of gp96 on the cell surface of macrophages isolated from synovial fluid of patients with RA, compared with RA or control peripheral blood monocytes [62]. Together these observations suggest that gp96 is induced in RA, that it is released to the cell surface or into the extracellular space, suggesting that it may contribute to a self-perpetuating inflammation as a TLR ligand.

\section{Mechanism for Release of gp96 from the ER}

Gp96's ER localization is important for its physiological function and immune homeostasis. The post-translational trafficking of gp96 is regulated by aminoacyl-tRNA synthetaseinteracting multifunctional protein 1 (AIMP1), which forms a molecular complex with gp96 in mediating the retrieval of KDEL-containing gp96 from Golgi to the ER [31]. Under pathogenic circumstances this mechanism for the retention of gp96 in the ER fails, resulting in gp96 translocation to the cell surface. Using flow analytic cell surface staining, gp96 expression on the surface of human monocyte cell line (HL-60) and mouse primary splenocytes is increased after treatment with heat inactive E.coli [34]. Further, TLR4 activation results in dissociation of gp96 from AIMP1 by phosphorylation through TLR4/ MyD88-mediated JNK activation. Additionally gp96 cell surface expression is also induced by Imiquimod, a TLR7 ligand, but not by other TLR ligands [34]. The mechanism for the cell surface expression of gp96 and its release into the synovial fluid in patients with RA is not known. However, the presence of endogenous TLR4 ligands in RA synovial fluid [62, 69], suggests that the TLR4 signaling pathway may contribute.

\section{Recombinant gp96 Activates RA Synovial Macrophages}

Studies were performed to determine the role of gp96 in macrophage activation employing the N-terminal domain of gp96 [21]. Employing flow cytometry, TNFa was induced by gp96 at a higher frequency and intensity in RA synovial fluid macrophages, compared with RA peripheral monocytes or control monocytes. Further, incubation with gp96 induced the expression of both TNFa and IL-8 mRNA, which are significantly greater in RA synovial 
macrophages than in control macrophages. Notably, gp96 also induced the expression of TLR2 mRNA in a dose-dependent fashion, and the induction of TLR2 was greater in RA synovial than in control macrophages. TLR4 induction was not observed in either control or RA synovial macrophages.

\section{RA Synovial Fluid gp96 as a TLR2 Ligand}

Even though our studies employed highly purified gp96 to remove endotoxin, there is still the concern that endotoxin contamination may contribute to the results. Therefore we employed RA synovial fluid, free of endotoxin contamination, to determine if the endogenous gp96 present in fluid is capable of activating macrophages [62]. RA synovial fluid incubated with normal in vitro differentiated macrophages results in the induction of TNFa and IL-8. The macrophage activation induced by RA synovial fluid is inhibited by neutralizing antibodies to TLR2 or TLR4, regardless of the concentration of gp96. However, only activation induced by RA synovial fluids with high gp96 (>800 ng/ml) is suppressed by neutralizing anti-gp96 antibody, while no reduction was observed for synovial fluids with low gp96 (<400 ng/ml). These observations suggest that endogenous gp96 present in RA SF contributes to macrophage activation. Furthermore, neutralizing antibodies to gp96 suppresses the activation of HEK-TLR2 cells by RA synovial fluids with high gp96 (>800 $\mathrm{ng} / \mathrm{ml}$ ). In contrast the neutralizing antibodies to gp96 did not suppress activation of HEKTLR4 cells by RA synovial fluids. Together, these observations demonstrate that gp96 present in RA synovial fluids is capable of activating macrophages mediated through TLR2 signaling. Importantly, the gp96 that is present in the RA synovial fluids is free of the potential endotoxin contamination, directly demonstrating the pathogenic potential of gp96 as endogenous TLR ligand in RA.

\section{The Therapeutic Potential of Targeting gp96}

\section{Experimental Model of Arthritis}

In order to determine the potential of targeting gp96, we employed an experimental model of RA. We utilized serum from $\mathrm{K} / \mathrm{BxN}$ mice containing antibodies to glucose-6-phosphate isomerase (anti-GPI) which was transferred into C57BL/6 mice, resulting in an immune complex mediated arthritis. Gp96 expression in the joints is minimal by ELISA and Western blot prior to arthritis induction but increases over time and peaking on day 9 and remaining elevated through day 12 before declining. The local expression of gp96 is highly correlated with inflammation documented by clinical exam, and with the presence of IL- $1 \beta$, which is critical to the pathogenesis of this disease [62].

\section{Targeting gp96 in RA and Experimental Model of Arthritis}

Neutralizing anti-gp96 antibodies have been shown to inhibit the recombinant gp96-induced TNF $a$ and IL-6 expression by macrophages [21], as well as the RA synovial fluid induced macrophage and HEK-TLR2 cell activation [62]. Further, ex vivo culture of the RA synovial fluid macrophages in the presence of neutralizing anti-gp96 serum results in suppression of the constitutively expressed TNF a [62]. We employed these antibodies, which also bind murine gp96, to determine the effect on the serum transfer arthritis model. Neutralizing antigp96 antibodies ameliorates of the progression and severity of anti-GPI induced arthritis [62]. Mice treated with the anti-gp96 antibodies experience a more rapid reduction of arthritis compared to mice treated with the control serum, as measured by clinical score and ankle thickness. Histological examination of the joints obtained also demonstrates a significant reduction of joint inflammation and extra-articular inflammation in mice treated with the anti-gp96 antibodies. Even though the neutralizing antibodies were administered before the peak expression of gp96, improvement in arthritis was only observed after the endogenous gp96 peaked. These observations support the potential role of gp96 in the 
perpetuation and progression of RA [62]. Studies to determine the effect of deletion of gp96 on arthritis would be complicated by the fact that deletion of gp96 is embryonically lethal, while the conditional deletion of gp96 in macrophages results in unresponsiveness to TLR ligands, since gp96 is necessary to chaperone TLRs to the appropriate membranes [28]. Supporting the role of endogenous TLR2 ligands in the pathogenesis of RA, the addition of neutralizing anti-TLR2 antibodies to ex vivo cultures of RA synovial tissue, results in suppression of TNF a to a similar degree as the TNF inhibitor etanercept [70]. Together, these observations suggest that inflammation initially induced by immune complexes promotes a positive feedback loop in RA through the induction of endogenous TLR ligands (Figure 1). Many gp96 inhibitors have also been developed for cancer therapy and are currently under phase I-III clinical trials [15, 71]. Other promising inhibitors are still in development $[72,73]$. However, their potential role as therapeutic agents to inhibit gp96 and TLR signaling in autoimmune diseases such as RA remains to be determined.

\section{Gp96 in Other Autoimmune Diseases}

\section{Role of gp96 in Other Autoimmune Diseases}

To examine the role of cell surface gp96 in the pathogenesis of autoimmunity, mice were genetically constructed to express cell surface gp96 [74]. The targeting of gp96 to the cell surface in a transgenic mouse model results in systemic lupus erythrmatosus (SLE)-like phenotype that includes glomerulonephritis, pneumonitis, hepatitis and endocarditis [74]. The lupus-like phenotype is associated with the increased expression of TLR4 on the cell surface [8]. Commensal gut flora is also required for disease development, suggesting that endotoxin release from the gut flora promotes inflammation by interaction with the TLR4 which was increased in the gp96 transgenic mice [8]. Consistent with our observations, gp96 did not activate through TLR4 [8]. These authors found that the increased activation through TLR4, suppresses T regulatory cell function, promoting the lupuslike disease [75].

Additionally, it was reported earlier that $30 \%$ of patients with SLE possess increased circulating autoantibody titers to gp96 [76]. Another group reported the increased antibody titers to gp96 not only in SLE, but also in patients with RA, tested within 6-12 months of symptom onset [38]. These observations suggest that gp96 may also serve as an autoantigen, which is independent of exposure to bacteria, since gp96 is only expressed in eukaryotic cells.

Gp96 has also been implicated in ischemic renal disease. During renal ischemia/reperfusion injury, hypoxia stimulates the expression of gp96, which was co-immunoprecipitated with TLR4. Silencing gp96 mRNA expression impaired hypoxia-induced apoptosis in TLR4expressing renal tubule epithelial cells [77]. TLR2 was also markedly upregulated in patients with chronic renal injury, associated with tissue fibrosis and chronic inflammation.

Supporting the role of TLR2 in a mouse model with obstructive nephropathy the upregulated expression of TLR2 is associated with increased gp96, biglycan and HMGB1 [78]. These observations suggest a role for gp96 in conditions other than RA.

\section{Targeting gp96 in Other Autoimmune Diseases}

As mentioned above, the forced cell surface expression of gp96 results in a lupus-like disease. The deletion of AIMPI, which results in deficient in gp96 ER retention, results in increased gp96 cell surface expression and a lupus-like autoimmune disease, similar to the phenotypic observed in the gp96 cell surface transgenic mice [31]. Prevention of the cell surface expression of gp96 with small chemical compound that facilitated retrograde transport to the endoplasmic reticulum, suppresses the lupus-like disease observed in the AIMPI deficient mice [79]. Together, these observations suggest gp96 as a potential therapeutic target in autoimmune diseases such as SLE. 


\title{
8. Other Endogenous TLR Ligands in RA
}

\section{Tenacin $\mathbf{C}$ in RA}

Tenacin $\mathrm{C}$ is an extracellular matrix glycoprotein and one of the well characterized potential DAMPs in arthritic joint disease. It is not expressed in healthy synovium but expressed upon tissue injury and elevated in the rheumatoid joint [80]. Tenacin C, free of endotoxin, was identified as an endogenous TLR4 activator essential for maintaining inflammation in an immune complex model of arthritis [81]. Further, tenacin C plays a role in DC-mediated polarization of Th17 lymphocytes, supporting its potential role in driving adaptive immunity which results in erosive joint disease [80]. Together, these observations suggest that like gp96, the initial inflammation induces the expression of Tenacin C, which then promotes the persistence of arthritis mediated through TLR4.

\section{Snapin in RA}

Snapin (SNAP - associated protein) is a protein originally identified as important in neurons for synchronization of synaptic vesicle fusion and late endosomal transport. Snapin was identified in a yeast 2-hybred screen using the extracellular domain of TLR2 as the bait and proteins expressed by actively inflamed RA synovial tissue as the prey. Snapin was the most frequently identified RA synovial tissue protein capable of interacting with TLR2. This was confirmed by immunoprecipitation assays. Further study demonstrated that Snapin was weakly expressed in non-inflammatory control synovial tissue but highly expressed in RA synovial tissue, especially in macrophages, where it co-localizes with Rab7 in late endosomes. Snapin expression in synovial tissue correlates with inflammation and is capable of activating through TLR2 [82]. Further, the activation of macrophages by RA synovial tissue was suppressed by antibodies to Snapin. These observations support the role of Snapin as a pathogenic endogenous TLR2 ligand in RA.

\section{Conclusion}

The mechanisms that contribute to the persistent activation of macrophages in RA are still not completely understood. This article reviewed the role of HSP member gp96 in the physiological and pathologic regulation of autoimmune disease, such as RA. Macrophages play a central role in regulating innate and adaptive immunity, and are a major source of proinflammatory cytokines and chemokines. During the inflammatory process induced by immune complexes, endogenous TLR ligands, such as gp96, Snapin and Tenacin C, are induced which act as DAMPs stimulating TLR signaling to produce pro-inflammatory cytokines and chemokines, leading to the persistent activation of macrophage, which results in a self-perpetuating inflammatory process. These observations provide the insights into the potential role of endogenous TLR ligands and the TLR signaling pathway as the novel therapeutic targets in RA (Figure 1).

\section{Acknowledgments}

This work was supported by grants from the National Institutes of Health (AR055240 and P60 AR048098) and a Within Our Reach grant from the American College of Rheumatology.

\author{
Abbreviations \\ DAMPs Danger Associated Molecular Patterns \\ ER Endoplasmic reticulum \\ gp96 Glycoprotein gp96
}




$\begin{array}{ll}\text { HSP } & \text { heat shock protein } \\ \text { PAMPs } & \text { Pathogen Associated Molecular Patterns } \\ \text { RA } & \text { Rheumatoid arthritis } \\ \text { TLR } & \text { Toll-like receptor }\end{array}$

\section{References}

1. Routsias JG, Tzioufas AG. Annals of the New York Academy of Sciences. 2006; 1088:52-64. [PubMed: 17192556]

2. Kampinga HH, Hageman J, Vos MJ, Kubota H, Tanguay RM, Bruford EA, Cheetham ME, Chen B, Hightower LE. Cell stress \& chaperones. 2009; 14:105-111. [PubMed: 18663603]

3. Hartl FU, Hayer-Hartl M. Science. 2002; 295:1852-1858. [PubMed: 11884745]

4. Tsan MF, Gao B. Journal of leukocyte biology. 2009; 85:905-910. [PubMed: 19276179]

5. Yang Y, Li Z. Molecules and cells. 2005; 20:173-182. [PubMed: 16267390]

6. Zhao R, Davey M, Hsu YC, Kaplanek P, Tong A, Parsons AB, Krogan N, Cagney G, Mai D, Greenblatt J, Boone C, Emili A, Houry WA. Cell. 2005; 120:715-727. [PubMed: 15766533]

7. Marzec M, Eletto D, Argon Y. Biochimica et biophysica acta. 2012; 1823:774-787. [PubMed: 22079671]

8. Liu B, Yang Y, Dai J, Medzhitov R, Freudenberg MA, Zhang PL, Li Z. J Immunol. 2006; 177:6880-6888. [PubMed: 17082602]

9. Brinker A, Scheufler C, Von Der Mulbe F, Fleckenstein B, Herrmann C, Jung G, Moarefi I, Hartl FU. The Journal of biological chemistry. 2002; 277:19265-19275. [PubMed: 11877417]

10. Akira S, Uematsu S, Takeuchi O. Cell. 2006; 124:783-801. [PubMed: 16497588]

11. Huang QQ, Pope RM. Curr Rheumatol Rep. 2009; 11:357-364. [PubMed: 19772831]

12. O'Neill LA. Nature clinical practice. Rheumatology. 2008; 4:319-327.

13. Jung YO, Cho ML, Kang CM, Jhun JY, Park JS, Oh HJ, Min JK, Park SH, Kim HY. Immunol Lett. 2007; 109:21-27. [PubMed: 17289161]

14. Vabulas RM, Wagner H, Schild H. Current topics in microbiology and immunology. 2002; 270:169-184. [PubMed: 12467251]

15. Randazzo M, Terness P, Opelz G, Kleist C. International journal of cancer. Journal international du cancer. 2012; 130:2219-2231. [PubMed: 22052568]

16. Multhoff G. Handbook of experimental pharmacology. 2006:279-304. [PubMed: 16610364]

17. Berwin B, Hart JP, Rice S, Gass C, Pizzo SV, Post SR, Nicchitta CV. Embo J. 2003; 22:61276136. [PubMed: 14609958]

18. Roelofs MF, Boelens WC, Joosten LA, Abdollahi-Roodsaz S, Geurts J, Wunderink LU, Schreurs BW, van den Berg WB, Radstake TR. J Immunol. 2006; 176:7021-7027. [PubMed: 16709864]

19. Vabulas RM, Ahmad-Nejad P, da Costa C, Miethke T, Kirschning CJ, Hacker H, Wagner H. The Journal of biological chemistry. 2001; 276:31332-31339. [PubMed: 11402040]

20. Asea A, Rehli M, Kabingu E, Boch JA, Bare O, Auron PE, Stevenson MA, Calderwood SK. The Journal of biological chemistry. 2002; 277:15028-15034. [PubMed: 11836257]

21. Huang QQ, Sobkoviak R, Jockheck-Clark AR, Shi B, Mandelin AM 2nd, Tak PP, Haines GK 3rd, Nicchitta CV, Pope RM. J Immunol. 2009; 182:4965-4973. [PubMed: 19342676]

22. Warger T, Hilf N, Rechtsteiner G, Haselmayer P, Carrick DM, Jonuleit H, von Landenberg P, Rammensee HG, Nicchitta CV, Radsak MP, Schild H. The Journal of biological chemistry. 2006; 281:22545-22553. [PubMed: 16754684]

23. Tsan MF, Gao B. American journal of physiology. Cell physiology. 2004; 286:C739-C744. [PubMed: 15001423]

24. Gao B, Tsan MF. The Journal of biological chemistry. 2003; 278:22523-22529. [PubMed: 12686536]

25. Gao B, Tsan MF. The Journal of biological chemistry. 2003; 278:174-179. [PubMed: 12403778] 
26. Melnick J, Aviel S, Argon Y. The Journal of biological chemistry. 1992; 267:21303-21306. [PubMed: 1400441]

27. Randow F, Seed B. Nat Cell Biol. 2001; 3:891-896. [PubMed: 11584270]

28. Yang Y, Liu B, Dai J, Srivastava PK, Zammit DJ, Lefrancois L, Li Z. Immunity. 2007; 26:215226. [PubMed: 17275357]

29. Melnick J, Dul JL, Argon Y. Nature. 1994; 370:373-375. [PubMed: 7913987]

30. Korbelik M, Sun J, Cecic I. Cancer research. 2005; 65:1018-1026. [PubMed: 15705903]

31. Han JM, Park SG, Liu B, Park BJ, Kim JY, Jin CH, Song YW, Li Z, Kim S. The American journal of pathology. 2007; 170:2042-2054. [PubMed: 17525271]

32. Berwin B, Reed RC, Nicchitta CV. J Biol Chem. 2001; 276:21083-21088. [PubMed: 11279246]

33. Basu S, Binder RJ, Suto R, Anderson KM, Srivastava PK. Int Immunol. 2000; 12:1539-1546. [PubMed: 11058573]

34. Kim G, Han JM, Kim S. Biochemical and biophysical research communications. 2010; 397:100105. [PubMed: 20510162]

35. Altmeyer A, Maki RG, Feldweg AM, Heike M, Protopopov VP, Masur SK, Srivastava PK. International journal of cancer. Journal international du cancer. 1996; 69:340-349. [PubMed: 8797880]

36. Zheng H, Dai J, Stoilova D, Li Z. J Immunol. 2001; 167:6731-6735. [PubMed: 11739487]

37. Morito D, Nagata K. Frontiers in immunology. 2012; 3:48. [PubMed: 22566930]

38. Weber CK, Haslbeck M, Englbrecht M, Sehnert B, Mielenz D, Graef D, Distler JH, Mueller RB, Burkhardt H, Schett G, Voll RE, Furnrohr BG. Rheumatology (Oxford). 2010; 49:2255-2263. [PubMed: 20716673]

39. Li Z, Menoret A, Srivastava P. Current opinion in immunology. 2002; 14:45-51. [PubMed: 11790532]

40. Yokota S, Fujii N. Microbiology and immunology. 2010; 54:299-307. [PubMed: 20536727]

41. Suriano R, Ghosh SK, Chaudhuri D, Mittelman A, Banerjee A, Tiwari RK. Glycobiology. 2009; 19:1427-1435. [PubMed: 19578160]

42. Brooks JC, Sun W, Chiosis G, Leifer CA. Biochemical and biophysical research communications. 2012; 421:780-784. [PubMed: 22554506]

43. Wu S, Hong F, Gewirth D, Guo B, Liu B, Li Z. The Journal of biological chemistry. 2012; 287:6735-6742. [PubMed: 22223641]

44. McInnes IB, Schett G. N Engl J Med. 2011; 365:2205-2219. [PubMed: 22150039]

45. Pope RM. Nat Rev Immunol. 2002; 2:527-535. [PubMed: 12094227]

46. Klareskog L, Catrina AI, Paget S. Lancet. 2009; 373:659-672. [PubMed: 19157532]

47. Firestein GS. Nature. 2003; 423:356-361. [PubMed: 12748655]

48. Wijbrandts CA, Vergunst CE, Haringman JJ, Gerlag DM, Smeets TJ, Tak PP. Arthritis and rheumatism. 2007; 56:3869-3871. [PubMed: 17968928]

49. Maciejewska Rodrigues H, Jungel A, Gay RE, Gay S. Molecular immunology. 2009; 47:12-18. [PubMed: 19232437]

50. Iwahashi M, Yamamura M, Aita T, Okamoto A, Ueno A, Ogawa N, Akashi S, Miyake K, Godowski PJ, Makino H. Arthritis and rheumatism. 2004; 50:1457-1467. [PubMed: 15146415]

51. Sorensen LK, Havemose-Poulsen A, Sonder SU, Bendtzen K, Holmstrup P. J Periodontol. 2008; 79:477-485. [PubMed: 18315430]

52. Huang Q, Ma Y, Adebayo A, Pope RM. Arthritis and rheumatism. 2007; 56:2192-2201. [PubMed: 17599732]

53. Radstake TR, Roelofs MF, Jenniskens YM, Oppers-Walgreen B, van Riel PL, Barrera P, Joosten LA, van den Berg WB. Arthritis and rheumatism. 2004; 50:3856-3865. [PubMed: 15593217]

54. Seibl R, Birchler T, Loeliger S, Hossle JP, Gay RE, Saurenmann T, Michel BA, Seger RA, Gay S, Lauener RP. The American journal of pathology. 2003; 162:1221-1227. [PubMed: 12651614]

55. Kim KW, Cho ML, Lee SH, Oh HJ, Kang CM, Ju JH, Min SY, Cho YG, Park SH, Kim HY. Immunol Lett. 2007; 110:54-64. [PubMed: 17467812] 
56. Ospelt C, Brentano F, Rengel Y, Stanczyk J, Kolling C, Tak PP, Gay RE, Gay S, Kyburz D. Arthritis and rheumatism. 2008; 58:3684-3692. [PubMed: 19035519]

57. Roelofs MF, Joosten LA, Abdollahi-Roodsaz S, van Lieshout AW, Sprong T, van den Hoogen FH, van den Berg WB, Radstake TR. Arthritis and rheumatism. 2005; 52:2313-2322. [PubMed: 16052591]

58. Shahrara S, Huang Q, Mandelin AM 2nd, Pope RM. Arthritis research \& therapy. 2008; 10:R93. [PubMed: 18710567]

59. Hu X, Chakravarty SD, Ivashkiv LB. Immunol Rev. 2008; 226:41-56. [PubMed: 19161415]

60. Kyburz D, Rethage J, Seibl R, Lauener R, Gay RE, Carson DA, Gay S. Arthritis and rheumatism. 2003; 48:642-650. [PubMed: 12632416]

61. Pierer M, Rethage J, Seibl R, Lauener R, Brentano F, Wagner U, Hantzschel H, Michel BA, Gay RE, Gay S, Kyburz D. J Immunol. 2004; 172:1256-1265. [PubMed: 14707104]

62. Huang QQ, Koessler RE, Birkett R, Dorfleutner A, Perlman H, Kenneth Haines G 3rd, Stehlik C, Nicchitta CV, Pope RM. Arthritis Rheum. 2012

63. Piccinini AM, Midwood KS. Mediators of inflammation. 2010; 2010

64. Huang Q, Pope RM. Journal of leukocyte biology. 2010; 88:253-262. [PubMed: 20484668]

65. Goh FG, Midwood KS. Rheumatology (Oxford). 2012; 51:7-23. [PubMed: 21984766]

66. Okamura Y, Watari M, Jerud ES, Young DW, Ishizaka ST, Rose J, Chow JC, Strauss JF 3rd. The Journal of biological chemistry. 2001; 276:10229-10233. [PubMed: 11150311]

67. Park JS, Svetkauskaite D, He Q, Kim JY, Strassheim D, Ishizaka A, Abraham E. The Journal of biological chemistry. 2004; 279:7370-7377. [PubMed: 14660645]

68. Schaefer L, Babelova A, Kiss E, Hausser HJ, Baliova M, Krzyzankova M, Marsche G, Young MF, Mihalik D, Gotte M, Malle E, Schaefer RM, Grone HJ. J Clin Invest. 2005; 115:2223-2233. [PubMed: 16025156]

69. Abdollahi-Roodsaz S, Joosten LA, Roelofs MF, Radstake TR, Matera G, Popa C, van der Meer JW, Netea MG, van den Berg WB. Arthritis and rheumatism. 2007; 56:2957-2967. [PubMed: 17763416]

70. Ultaigh SN, Saber TP, McCormick J, Connolly M, Dellacasagrande J, Keogh B, McCormack W, Reilly M, O'Neill LA, McGuirk P, Fearon U, Veale DJ. Arthritis research \& therapy. 2011; 13:R33. [PubMed: 21345222]

71. Kim YS, Alarcon SV, Lee S, Lee MJ, Giaccone G, Neckers L, Trepel JB. Current topics in medicinal chemistry. 2009; 9:1479-1492. [PubMed: 19860730]

72. Duerfeldt AS, Peterson LB, Maynard JC, Ng CL, Eletto D, Ostrovsky O, Shinogle HE, Moore DS, Argon Y, Nicchitta CV, Blagg BS. Journal of the American Chemical Society. 2012; 134:97969804. [PubMed: 22642269]

73. Moulick K, Ahn JH, Zong H, Rodina A, Cerchietti L, Gomes DaGama EM, Caldas-Lopes E, Beebe K, Perna F, Hatzi K, Vu LP, Zhao X, Zatorska D, Taldone T, Smith-Jones P, Alpaugh M, Gross SS, Pillarsetty N, Ku T, Lewis JS, Larson SM, Levine R, Erdjument-Bromage H, Guzman ML, Nimer SD, Melnick A, Neckers L, Chiosis G. Nature chemical biology. 2011; 7:818-826.

74. Liu B, Dai J, Zheng H, Stoilova D, Sun S, Li Z. Proceedings of the National Academy of Sciences of the United States of America. 2003; 100:15824-15829. [PubMed: 14668429]

75. Dai J, Liu B, Ngoi SM, Sun S, Vella AT, Li Z. J Immunol. 2007; 178:3219-3225. [PubMed: 17312170]

76. Boehm J, Orth T, Van Nguyen P, Soling HD. European journal of clinical investigation. 1994; 24:248-257. [PubMed: 8050453]

77. Ben Mkaddem S, Pedruzzi E, Werts C, Coant N, Bens M, Cluzeaud F, Goujon JM, Ogier-Denis E, Vandewalle A. Cell death and differentiation. 2010; 17:1474-1485. [PubMed: 20224597]

78. Leemans JC, Butter LM, Pulskens WP, Teske GJ, Claessen N, van der Poll T, Florquin S. PloS one. 2009; 4:e5704. [PubMed: 19479087]

79. Han JM, Kwon NH, Lee JY, Jeong SJ, Jung HJ, Kim HR, Li Z, Kim S. PloS one. 2010; 5:e9792. [PubMed: 20352117]

80. Ruhmann M, Piccinini AM, Kong PL, Midwood KS. Arthritis and rheumatism. 2012; 64:2179_ 2190. [PubMed: 22275298] 
81. Midwood K, Sacre S, Piccinini AM, Inglis J, Trebaul A, Chan E, Drexler S, Sofat N, Kashiwagi M, Orend G, Brennan F, Foxwell B. Nat Med. 2009; 15:774-780. [PubMed: 19561617]

82. Shi B, Huang Q, Tak PP, Vervoordeldonk MJ, Huang CC, Dorfleutner A, Stehlik C, Pope RM. Annals of the rheumatic diseases. 2012 
- Glycoprotein (gp) 96 is a resident ER chaperone.

- Gp96 is increased in rheumatoid arthritis synovial tissue and fluid.

- Gp96 binds to and activates TLR2, promoting chronic inflammation.

- Neutralization of gp96 ameliorates experimental arthritis. 


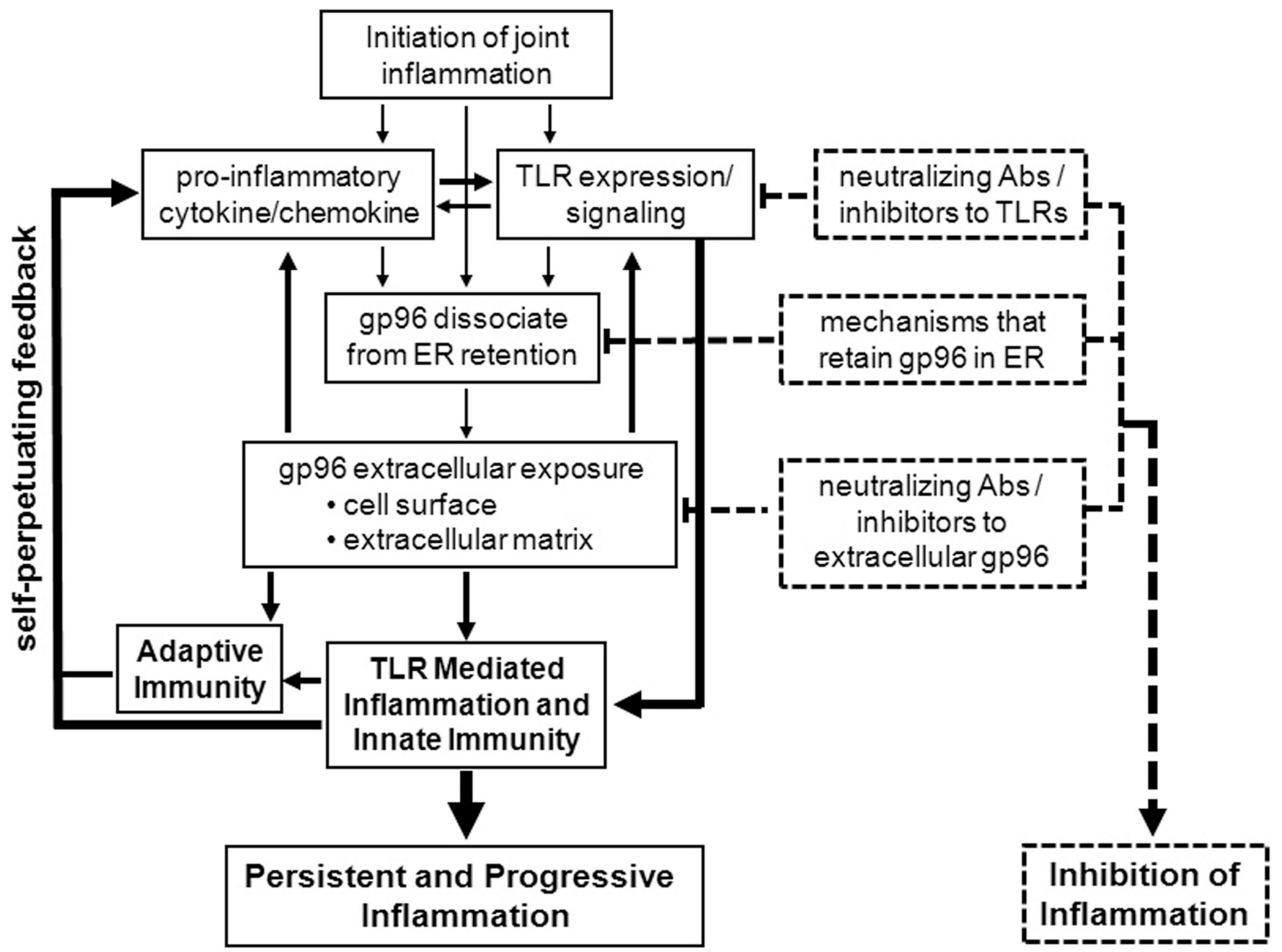

Figure 1. Schematic summary of endogenous gp96 in TLR2 mediated macrophage activation in RA and strategies for therapeutic intervention

The initiating events that induce joint inflammation stimulate macrophages within the joints to produce pro-inflammatory cytokines and/or chemokines relate to environmental exposure of genetically predisposed individuals who then develop autoantibodies which result in pathogenic immune complexes. Inflammation also stimulates macrophage mediated innate immunity by increased TLR 2 expression and responsiveness to TLR 2 ligands. Following the induction of inflammation, gp96 is dissociated from ER retention and traffics to cell membrane or is released to extracellular matrix, which allows gp96 to interact with TLR2 on the surface of macrophages and other cells, resulting in persistent and progressive activation. The arrows and solid lines indicate increased activation and the self-perpetuating cycle.

Therapeutic approaches targeting these steps to break this cycle are identified by dotted lines or arrows. 